3-1-2003

\title{
Things Have Changed: Looking at Non-Institutional Mental Disability Law Through the Sanism Filter
}

Michael L. Perlin

New York Law School, michael.perlin@nyls.edu

Follow this and additional works at: https://digitalcommons.nyls.edu/fac_articles_chapters

\section{Recommended Citation}

46 N.Y.L. Sch. L. Rev. 3-4

This Article is brought to you for free and open access by the Faculty Scholarship at DigitalCommons@NYLS. It has been accepted for inclusion in Articles \& Chapters by an authorized administrator of DigitalCommons@NYLS. 


\title{
"THINGS HAVE CHANGED:"1 \\ LOOKING AT NON-INSTITUTIONAL MENTAL DISABILITY LAW THROUGH THE SANISM FILTER
}

\begin{abstract}
Michael L. Perlin*
I have been writing about mental disability law for over 25 years, dating back to my days as Director of New Jersey's Division of Mental Health Advocacy. ${ }^{2}$ My scholarship has proceeded through many phases, ${ }^{3}$ but, in the past decade, I have come to focus more and more on what I call "sanism" and what I call "pretextuality."
\end{abstract}

1. Boв Dylan, Things Have Changed, on The Essential Bob Dylan 2000 (Columbia 2000).

* Professor Michael L. Perlin is a Professor or Law at New York Law School. Rutgers University, B.A. 1966; Columbia University School of Law, J.D. 1969.

2. For articles from that time period, see, e.g., Michael L. Perlin, An Invitation to the Dance: An Empirical Response to Chief Justice Warren Burger's "Time-Consuming Procedural Minuets" Theory in Parham v. J.R., 9 Bull. Am. Acad. Psychiatry \& L. 149 (1981); Michael L. Perlin, The Right to Participate in Voluntary, Therapeutic, Compensated Work Programs as Part of the Right to Treatment: A New Theory in the Aftermath of Souder, 7 SETON Hall L. Rev. 298 (1976); Joseph Rodriguez et al., Proportionality Review in New Jersey: An Indispensable Safeguard in the Capital Sentencing Process, 15 Rutgers L.J. 399 (1984); Joseph Rodriguez et al., The Insanity Defense Under Siege: Legislative Assaults and Legal Rejoinders, 14 Rutgers L.J. 397 (1983); Michael L. Perlin \& Robert L. Sadoff, Ethical Issues in the Representation of Individuals in the Commitment Process, 45 Law \& Contemp. Probs. 161 (1982).

3. For a sampling of doctrinal articles written in my earlier days as an academic, see, e.g., Michael L. Perlin, Are Courts Competent to Decide Questions of Competency? Stripping the Façade From United States v. Charters, 38 U. Kan. L. Rev. 957 (1990); Michael L. Perlin, State Constitutions and Statutes as Sources of Rights for the Mentally Disabled: The Last Frontier?, 20 Loyola L.A. L. Rev. 1249 (1987); Michael L. Perlin, The Supreme Court, the Mentally Disabled Criminal Defendant, and Symbolic Values: Random Decisions, Hidden Rationales, or "Doctrinal Abyss?," 29 Ariz. L. Rev. 1 (1987); Michael L. Perlin, Ten Years After: Evolving Mental Health Advocacy and Judicial Trends, 15 Fordham Urban L.J. 335 (198687); Michael L. Perlin, The Supreme Court, the Mentally Disabled Criminal Defendant, Psychiatric Testimony in Death Penalty Cases, and the Power of Symbolism: Dulling the Ake in Barefoot's Achilles Heel, 3 N.Y.L. Sch. Human Rts. Ann. 91 (1985); Michael L. Perlin, Unpacking the Myths: The Symbolism Mythology of Insanity Defense Jurisprudence, 40 CASE W. REs. L. REv. 599 (1989-90).

4. See, e.g., Michael L. Perlin, The Hidden Prejudice: Mental Disability on Trial (2000) [hereinafter Hidden Prejudice]; Michael L. Perlin, "Half-Wracked Prejudice Leaped Forth:" Sanism, Pretextuality, and Why and How Mental Disability Law Developed As It Did, 10 J. Contemp. Leg. Issues 3 (1999) [hereinafter Half-Wracked]. 


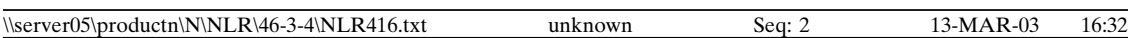

I define "sanism" as "an irrational prejudice of the same quality and character of other irrational prejudices that cause (and are reflected in) prevailing social attitudes of racism, sexism, homophobia, and ethnic bigotry." 5 It infects both our jurisprudence and our lawyering practices. ${ }^{6}$ Sanism is largely invisible, and largely socially acceptable. It is based predominantly upon stereotype, myth, superstition, and deindividualization. It is sustained and perpetuated by our use of alleged "ordinary common sense" ("OCS") and heuristic reasoning in an unconscious response to events both in everyday life and in the legal process. ${ }^{7}$

"Pretextuality" means that courts accept (either implicitly or explicitly) testimonial dishonesty and engage in similarly dishonest (frequently meretricious) decision-making, specifically where witnesses, especially expert witnesses, show a "high propensity to purposely distort their testimony in order to achieve desired ends." ${ }^{8}$ This pretextuality is poisonous. It infects all participants in the judicial system, breeds cynicism and disrespect for the law, demeans participants, and reinforces shoddy lawyering, blasé judging, and, at times, perjurious and/or corrupt testifying. ${ }^{9}$

I am convinced that it is impossible to understand any aspect of mental disability law without understanding the corrosive and malignant impact of these factors. ${ }^{10}$ I wrote my most recent book, THE Hid-

5. See Michael L. Perlin, On "Sanism," 46 SMU L. Rev. 373 (1992). The classic treatment is Gordon Allport, The Nature of Prejudice (1955). For an important, more recent, and different perspective, see Elisabeth Young-Bruehl, The Anatomy of Prejudices (1996).

6. To the best of my knowledge, Dr. Morton Birnbaum coined the phrase "sanism." He is universally regarded as having first developed and articulated the constitutional basis of the right to treatment doctrine for institutionalized mental patients. E.g., Morton Birnbaum, The Right to Treatment, 46 A.B.A. J. 499 (1960). See Michael L. Perlin, Competency, Deinstitutionalization, and Homelessness: A Story of Marginalization, 28 Hous. L. Rev. 63, 92-93 (1991) (discussing Birnbaum's insights). See also Koe v. Califano, 573 F. 2d 761, 764 (2d. Cir. 1978).

7. Michael L. Perlin, Psychodynamics and the Insanity Defense: "Ordinary Common Sense" and Heuristic Reasoning, 69 Neb. L. Rev. 3 (1990). I discuss heuristics and "ordinary common sense" extensively in Perlin, Half-Wracked, supra note 4, at 3-20.

8. Charles Sevilla, The Exclusionary Rule and Police Perjury, 11 SAn Diego L. Rev. 839, 840 (1974); see also Michael L. Perlin, Morality and Pretextuality, Psychiatry and Law: Of "Ordinary Common Sense," Heuristic Reasoning, and Cognitive Dissonance, 19 Bull. Am. Acad. Psychiatry \& L. 131, 133 (1991).

9. See generally Michael L. Perlin, Pretexts and Mental Disability Law: The Case of Competency, 47 U. Miami L. Rev. 625 (1993).

10. See Perlin, Hidden Prejudice, supra note 4, at xv-xxv. 


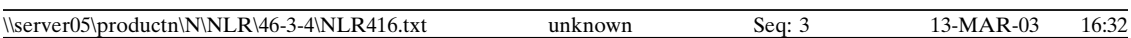

den Prejudice: Mental Disability on Trial, ${ }^{11}$ to illuminate this impact, to cast some light on why mental disability law has developed this way, and to indicate what the implications are for the future of this area of the law. I did this by looking at those areas of the law that I write and teach about (and almost all of which I practiced in): involuntary civil commitment, institutional rights law, the Americans with Disabilities Act, sexual autonomy, and all aspects of the criminal trial process. ${ }^{12}$

Each one of these legal subjects and just about all the mental disability law topics that I have and continue to write about, with the exception of Tarasoff/"psychiatric torts" issues, ${ }^{13}$ deal primarily with one discrete population: persons who are subject to commitment to inpatient psychiatric hospitals. Some of my writing has looked at the involuntary civil commitment process, ${ }^{14}$ some at the treatment of persons once institutionalized, ${ }^{15}$ some at their treatment in the community once released, ${ }^{16}$ and some at the intersection between mental disability law and the criminal trial process. ${ }^{17}$ Nevertheless, it has dealt with questions of institutionalization, and, by and large, these are questions that affect poor people. ${ }^{18}$ This is certainly not to say that mental illness is limited to persons of low economic status, but rather, invariably, by the time a person becomes subject to the involuntary civil commitment process, there is an excellent chance she is indigent.

Of course, problems of mental disability are not solely institutional problems. A significant percentage of the public - the vast majority of which will never be in peril of institutionalization - exhibit some sort of serious mental illness during their lifetime. ${ }^{19}$ A much

11. Id.

12. Id. at 79-112 (involuntary civil commitment), 125-56 (right to refuse treatment), 157-74 (right to sexual interaction), 175-204 (Americans with Disabilities Act), 205-22 (competency to plead guilty/waive counsel), 223-44 (the insanity defense).

13. See, e.g., Michael L. Perlin, Tarasoff and the Dilemma of the Dangerous Patient: New Directions for the 1990's, 16 Law \& Psychol. Rev. 29 (1992).

14. See, e.g., Michael L. Perlin, Mental Disability Law: Civil and Criminal chs. 2A, 2C (2d ed. 1998) [hereinafter Civil and Criminal].

15. See, e.g., id. at chs. 3A-3C (2d ed. 1999).

16. See, e.g., id. at chs. 4A-4C (2d ed. 2000).

17. See, e.g., $i d$. at chs. 9-12 (2d ed. 2002).

18. On the question of the impact of a patient's "worth" on his treatment in the public mental health system, see Perlin, Hidden Prejudice, supra note 4, at 88.

19. $5.4 \%$ of Americans have a severe mental illness as measured by the criteria of the American Psychiatric Association's Diagnostic and Statistical Manual. See R.C. Kessler et al, A Methodology for Estimating the 12-Month Prevalence of Serious Mental Illness, in 


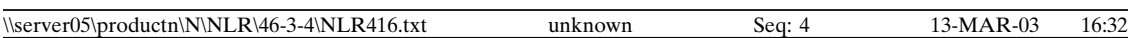

larger percentage exhibits some sign of mental disability or mental disorder. ${ }^{20}$ This population - like the rest of the population - frequently has problems that require resolution by a lawyer and the legal system. Such problems include issues regarding contracts, ${ }^{21}$ property, ${ }^{22}$ domestic relations, ${ }^{23}$ and trusts and estates. ${ }^{24}$

Several years ago, I published a casebook, titled, predictably, Mental Disability Law: Cases and Materials. ${ }^{25}$ Putting together the chapters in institutional mental disability law, and what I inartfully call "criminal mental disability law," posed one set of problems: so many cases and so few pages (though my students who have been schlepping this book around may disagree). In these areas there is a surfeit of cases, and I was faced with difficult questions of what to include and what to omit. When I did the first supplement, I encountered the same predicament. ${ }^{26}$ But, when I decided to include a non-constitutional, non-institutionally-based civil law chapter, my dilemma was very different: what to include? Again, putting aside psychiatric tort issues (about which there is enough material to sustain a casebook of its own), 27 there has been what appears at first glance to be a startling paucity of recent developments in almost all other areas of private civil law: ${ }^{28}$ just a handful of mostly-uninspired (and uninspiring) cases and a few student notes. I am satisfied that the selections I made were good ones, and continue to believe that they serve valuable pedagogic purposes. ${ }^{29}$ That said, I certainly did not give them the thought, atten-

Mental Health, United States, 1999 (R.W. Manderscheid \& M.J. Henderson eds. 1998).

20. $23 \%$ of Americans suffer from a diagnosable mental disorder in any given year. See D.A. Regier et al, Epidemiologic Catchment Are Prospective: One Year Prevalence Rates of Disorders and Services, 50 Arch. Gen'l Psychiatry 85 (1993).

21. See, e.g., Rudnitsky v. Rudnitsky, $2001 \mathrm{WL} 1671149$ (Del. Ch.).

22. See, e.g., Williams v. Williams, 73 S.W.3d 376 (Tex. App. 2002). 66.

23. See, e.g., Perlin, Civil and Criminal, supra note 14, at $§ 5$ A-2.4, p. 201, nn. 264-

24. See, e.g., Monahan v. Holmes, 139 F.Supp.2d 253 (D. Conn. 2001).

25. Michael L. Perlin, Mental Disability Law: Cases and Materials (1999) [hereinafter Cases and Materials].

26. See Michael L. Perlin, Mental Disability Law: Cases and Materials (2001 Supp.).

27. See Perlin, Civil and Criminal, supra note 14, at chs. 7A-7C.

28. The one exception involves the interrelationship between questions of parental rights, custody and adoptions and the Americans with Disabilities Act. See, e.g., PERLin, Civil and Criminal, supra note 14, at $\$ 5$ A-2.4, p. 201, nn. 264-66 (citing cases).

29. I included several domestic relations law cases: Matter of Sarah B., 610 N.Y.S.2d 403 (N.Y. App. Div. 3d. Dep't 1994); State of New Mexico ex rel. Children, 


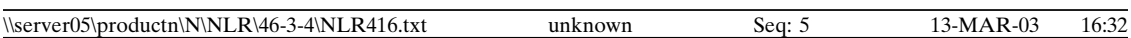

tion, and focus that I gave the cases and materials in the remaining chapters of the book.

So why is this? I can conjure a few possible explanations:

1. The Supreme Court made it clear thirty years ago that the due process clause applies to all institutional decision-making, ${ }^{30}$ and that all questions dealing with the "nature and duration" of commitment are constitutionally bound. ${ }^{31}$ As a result, the "high ticket" questions in the constitutional litigator's arsenal have come to play a role in institutional litigation, leading to an explosion of case law and commentary. ${ }^{32}$

2. The Supreme Court has remained fascinated - again, for three decades - with the full range of questions involving the intersection of the criminal trial process and mental disability law. ${ }^{33}$ The Court's fascination and resulting Supreme Court case law has translated into more scholarship and new lower court case decisions.

3. Issues of institutional mental disability law are contentious and are discussed in the public press, in both the serious and tabloid media. Questions of the proper scope of the involuntary civil commitment power (exemplified in New York by the debate over "assisted outpatient treatment" in the guise of "Kendra's Law"), ${ }^{34}$ the dispositions of cases involving so-called "sexually violent predators" (exempli-

Youth \& Families Dept v. John D., 934 P. 2d 308 (N.M. Ct. App. 1997); Seltzer v. Seltzer, 584 So.2d 710 (La. Ct. App. 1991). See Perlin, Cases and Materials, supra note 25, at 700-09. However, I have limited my wills and contracts references to Laura Wolfe, $A$ Clarification of the Standard of Mental Capacity in North Carolina for Legal Transactions of the Elderly, 32 WAKe Forest L. REv. 563 (1997).

30. Jackson v. Indiana, 406 U.S. 715, 731 (1972) ("Indiana's indefinite commitment of a criminal defendant solely on account of his incompetency to stand trial does not square with the Fourteenth Amendment's guarantee of due process.").

31. Id. at 738 ("At the least, due process requires that the nature and duration of commitment bear some reasonable relation to the purpose for which the individual is committed.").

32. I am far from the only mental disability law professor with extensive practice background in this field. See, e.g., the work of Susan Stefan, Jan Costello, or Arlene Kanter.

33. See, e.g., Michael L. Perlin, "No Direction Home:" The Law and Criminal Defendants With Mental Disabilities, 20 Mental \& Physical Disability L. Rep. 605 (1996).

34. See N.Y. Mental Hygiene Law $\$ 9.60$ (2002). See also Perlin, Civil and CrimiNAL, supra note 14 at $§ 2 \mathrm{C}-7.3$; Michael L. Perlin, Therapeutic Jurisprudence and Outpatient Commitment: Kendra's Law as Case Study, - Psychol. Pub. Pol'y \& L. - (2002) (in press). 


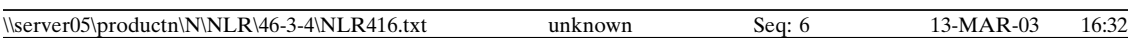

fied in New Jersey by the now world-famous "Megan's Law"), ${ }^{35}$ the authority of hospitals to involuntarily administer medication to institutionalized patient (both in civil and forensic settings), ${ }^{36}$ the application of the insanity defense in a handful of over-sensationalized cases, ${ }^{37}$ and the relationship between mental retardation and the death penalty, ${ }^{38}$ are all part of the public debate.

4. The passage of the Americans with Disabilities Act ${ }^{39}$ (although not typically seen as a law that focuses on the status of persons with mental disabilities $)^{40}$ has forced us to rethink questions of discrimination, segregation, and exclusion in a variety of settings. ${ }^{41}$ It has also to some extent, "fused" the mental disability law "movement" and the civil rights "movement." 42

5. Consumers (or "survivors") (or "stakeholders") (or "ex-patients") are beginning to receive some public attention as a political action force. ${ }^{43}$ While the National Alliance for the Mentally Ill ("NAMI") is the best known of these groups, ${ }^{44}$ there are many others,

35. See N.J. Stat. Ann §§ 2C: 7-1 et seq. See also Perlin, Civil and Criminal, supra note 14, at \$2A-3.3; Michael L. Perlin, "There's No Success like Failure/and Failure's No Success at All:" Exposing the Pretextuality of Kansas v. Hendricks, 92 Nw. U. L. Rev. 1247 (1998).

36. See Perlin, Civil and Criminal, supra note 14, at ch. 3B.

37. See generally, Michael L. Perlin, The Jurisprudence of the Insanity DeFEnse (1994); Michael L. Perlin, "The Borderline Which Separated You From Me:" The Insanity Defense, the Authoritarian Spirit, the Fear of Faking, and the Culture of Punishment, 82 IOwA L. REv. 1375 (1997).

38. In its most recent term, the Supreme Court held that execution of persons with mental retardation violates the Eighth Amendment. Atkins v. Virginia, 536 U.S. 304, 122 S.Ct. 2242 (2002).

39. 42 U.S.C. $\$ \S 12101$ et seq.

40. See, e.g., Michael L. Perlin, "I Ain't Gonna Work on Maggie’s Farm No More": Institutional Segregation, Community Treatment, the ADA, and the Promise of Olmstead v. L.C., 17 T.M. Cooley L. Rev. 53 (2000); Michael L. Perlin, "Make Promises by the Hour:" Sex, Drugs, the ADA, and Psychiatric Hospitalization, 46 DePAul L. Rev. 947 (1997); Michael L. Perlin, The ADA and Persons with Mental Disabilities: Can Sanist Attitudes Be Undone? 8 J. L. \& Health 15 (1993-94).

41. See Olmstead v. L.C., 527 U.S. 581 (1999).

42. See, e.g., Michael L. Perlin, "What's Good Is Bad, What's Bad Is Good, You'll Find Out When You Reach the Top, You're on the Bottom:" Are the Americans with Disabilities Act (and Olmstead v. L.C.) Anything More than "Idiot Wind?," 35 U. Mich. J.L. Reform. 235 (2002).

43. See, e.g., Michael L. Perlin, A Law of Healing, 68 U. CIN. L. Rev. 407, 414, n. 50 (2000); Rae E. Unzicker, From Privileges to Rights, 17 T.M. Cooley L. Rev. 171 (2000).

44. See, e.g., http://www.nami.org. 


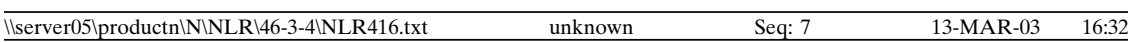

on all points of the political spectrum that continue to make important contributions to the ongoing debate. ${ }^{45}$

On the surface, none of these explanations appear to have very much to do with contracts law or trusts and estates law. Institutionalization is rarely an issue in such cases; the criminal trial process is not implicated; my legal research to date has revealed no Americans with Disabilities Act cases on point; ${ }^{46}$ the public debate about "mental disability and the law" never seems to touch on these issues; ${ }^{47}$ consumer groups do not list this as a priority. As a result of all this, perhaps, the legal academy has been to some extent uncharacteristically silent about this area of the law.

But is this as it should be? Is it possible that we - legal and behavioral scholars who write regularly about mental disability law - have truly missed the boat? I think we have. Are these areas of the law that we can continue to comfortably and unthinkingly marginalize? I don't think so.

When I started writing seriously about sanism, I asserted that it pervaded "all aspects of the mental disability law process." 48 I believed that then, and I believe it now. But for the reasons I have stated (and perhaps others), areas of private civil law such as trusts and estates have gotten a "free ride."

This should not be. If I am right about sanism's pervasiveness and its pernicious power, it should inevitably poison trusts and estates law just as it poisons involuntary civil commitment law or the right of institutionalized persons to sexual autonomy. If we stereotype persons with mental disabilities, "slot" them, stereotype them, deny them their social worth, emphasize their "differentness," distort their behavior, and trivialize their humanity - which is what we do in every area of mental disability law that I have taught, written about, or represented clients in - then it strains credulity to suggest that we do not do this in cases involving such areas of the law as trusts and estates. ${ }^{49}$

45. See, e.g., http://www.narpa.org.

46. A WESTLAW/ALLCASES search of "Americans with Disabilities Act" AND "trusts and estates," conducted on March 4, 2002, revealed no cases.

47. On the public's preoccupation with the supposed dangerousness of persons with mental illness, see Study: More People Associating Mental Illness with Violence, available at http://www.cnn.com/2000/HEALTH/09/27/mental.illness.ap (last visited Sept. 27, 2000).

48. Perlin, Hidden Prejudice, supra note 4, at 30.

49. See Falter v. United States, 502 F. Supp. 1178, 1185 (D. N.J. 1980) (the central inquiry is "how [persons with mental disabilities] are treated as human beings"). 


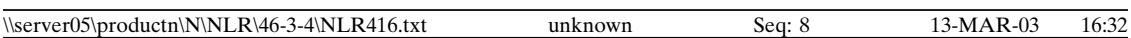

In fact, not only do we do it, but we most likely do it even more invisibly. One of the arguments that I regularly make in discussing sanism is that it is "invisible:" 50 that it takes place in closed courtrooms, and is reflected in sealed transcripts. ${ }^{51}$ It remains "under the radar screen" for most judges and other participants in the legal system. ${ }^{52}$ But, at least there are other legal scholars writing about it, ${ }^{53}$ and there are a handful of judges that have considered these issues in published decisions. ${ }^{54}$ A recent Montana case that established performance standards for lawyers in involuntary civil commitment matters is the most sophisticated example yet of a court carefully assessing these issues. ${ }^{55}$ And, not unimportantly, there is a sub-specialty "mental disability law bar" 56 that provides a cadre of dedicated lawyers whose sole job is to represent institutionalized individuals and those facing institutionalization. However, there is no such cadre in trust and estates law. And again, up until now, there has been no scholarship devoted to these issues.

50. See, e.g., Michael L. Perlin, "For the Misdemeanor Outlaw:" The Impact of the ADA on the Institutionalization of Criminal Defendants with Mental Disabilities, 52 Ala. L. Rev. 193, 227 (2000).

51. See, e.g., Michael L. Perlin, "Their Promises of Paradise:” Will Olmstead v. L.C. Resuscitate The Constitutional "Least Restrictive Alternative" Principle in Mental Disability Law?, 37 Houston L. Rev. 999, 1021 (2000).

52. See Perlin, supra note 42, at 249.

53. See, e.g., Peter Blanck, Civil War Pensions and Disability, 62 Онго Sт. L.J. 109, 203, n.309 (2001); Justine Dunlap, Mental Health Advance Directives: Having One's Say? 89 Ky. L.J. 327, 379-80 (2000-01); Grant Morris, The Evil That Men Do: Perverting Justice to Punish Perverts, 2000 U. ILl. L. Rev. 1199, 1201, n.13 (2000); Christopher Slobogin, An End to Insanity: Recasting the Role of Mental Disability in Criminal Cases, 86 VA. L. Rev. 1199, 1203-04 (2000); Bruce Winick, Therapeutic Jurisprudence and the Civil Commitment Hearing, 10 J. Contemp. Legal Issues 37, 41 (1999).

54. I discuss some of these cases in Perlin, Hidden Prejudice, supra note 4, at 307 08, and in Perlin, Half-Wracked, supra note 4, at 31-32 (discussing State v. Wilson, 700 A.2d 633, 649-50) (Conn. 1997) (Katz, J., concurring); United States v. Denny-Shaffer, 2 F.3d 999, 1009, 1021, n.30 (10th Cir. 1993); State Farm Fire \& Casualty Co. v. Wicka, 474 N.W.2d 324, 327 (Minn. 1991); and Waters v. Thomas, 46 F.3d 1506, 1535 (11th Cir. 1995) (Clark, J., concurring in part and dissenting in part)).

55. In re the Mental Health of K.G.F., 29 P.3d 485 (Mont. 2001) (scope of right to effective counsel includes appointment of competent counsel with specialized training, right to make informed decision on whether to accept counsel, right to thorough investigation of case by counsel, right to initial client interview with counsel, and right to have counsel present during patient's court-ordered mental health examination).

56. For an example of organized mental health advocacy systems, see, e.g., N.Y. Mental Hygiene Law $\$ 47.01$ (establishing Mental Hygiene Legal Services office); N.J. Stat. AnN § 52:27E-65 (restructuring Division of Mental Health Advocacy); 42 U.S.C. $\S 10807$ (establishing Protection and Advocacy Systems for Mentally Ill Individuals). 


\begin{tabular}{|c|c|c|c|}
\hline 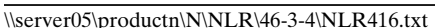 & unknown & Seq: 9 & 13-MAR-03 \\
\hline
\end{tabular}

There is one analogy that may be of help. At about the same point in time that I was first developing my ideas about sanism, Professors David Wexler and Bruce Winick were developing their ideas about "therapeutic jurisprudence" ("TJ"). TJ studies the role of the law as a therapeutic agent. ${ }^{57}$ This perspective recognizes that substantive rules, legal procedures, and lawyers' roles may have either therapeutic or anti-therapeutic consequences. It questions whether such rules, procedures, and roles can or should be reshaped so as to enhance their therapeutic potential, while not subordinating due process principles. ${ }^{58}$ Wexler, Winick, and their colleagues - myself included - immediately began to apply $\mathrm{TJ}$ principles to every aspect of the mental disability law system. ${ }^{59}$ I pounced on this approach, and began to use it as a basis of my discussions of involuntary civil commitment law, right to treatment law, right to refuse treatment law, and much more. ${ }^{60}$ In fact, in THE Hidden Prejudice, I devote my final chapter to a TJ "read" of all those aspects of mental disability law that I find to be sanist and pretextual,

57. See, e.g., David Wexler, Therapeutic Jurisprudence: New Directions in Law/Mental Health Scholarship, in Mental Health Law: Research, Policy and Services 357 (Bruce D. Sales \& Saleem S. Shah eds., 1996); Michael L. Perlin, Therapeutic Jurisprudence: Understanding the Sanist and Pretextual Bases of Mental Disability Law, 20 N. ENG. ON J. Crim. \& Civ. Confinement 369 (1994); Bruce Sales \& Daniel Shuman, Mental Health Law and Mental Health Care: Introduction, 64 Aм. J. Orthopsychiatry 172 (1994); David Wexler, Justice, Mental Health, and Therapeutic Jurisprudence, 40 CLEv. ST. L. REv. 517 (1992); David Wexler \& Bruce Winick, Therapeutic Jurisprudence as a New Approach to Mental Health Law Policy Analysis and Research, 45 U. Miami L. Rev. 979 (1991); David Wexler, Reflections on the Scope of Therapeutic Jurisprudence, 1 Psychol. Pub. Pol'y \& L. 220 (1995).

58. Christopher Slobogin, Therapeutic Jurisprudence: Five Dilemmas to Ponder, 1 Psychol. Pub. Pol'y \& L. 193 (1995); David Wexler, Health Care Compliance Principles and the Insanity Acquittee Conditional Release Process, 27 Crim. L. Bull. 18, 19 n.5 (1991); David Wexler, Therapeutic Jurisprudence: Restructuring Mental Disability Law, 10 N.Y.L. Sch. J. Hum. RTs. 759 (1993).

59. See, e.g., Michael L. Perlin et al., Therapeutic Jurisprudence and the Civil Rights of Institutionalized Mentally Disabled Persons: Hopeless Oxymoron or Path to Redemption?, 1 Psychol. Pub. Pol'y \& L. 80 (1995) [hereinafter Therapeutic Jurisprudence], reprinted in Law in a Therapeutic Key: Developments in Therapeutic Jurisprudence 739 (David B. Wexler \& Bruce J. Winick eds., 1996) [hereinafter KEY].

60. See, e.g., Keri Gould \& Michael L. Perlin, "Johnny's in the Basement/Mixing Up His Medicine:" Therapeutic Jurisprudence and Clinical Teaching, 24 Seattle U. L. Rev. 339, 366-71 (2000); Michael L. Perlin \& Deborah A. Dorfman, Is It More Than "Dodging Lions and Wastin' Time?" Adequacy of Counsel, Questions of Competence, and the Judicial Process in Individual Right to Refuse Treatment Cases, 2 Psychol. Pub. Pol'y \& L. 114 (1996) (right to refuse treatment); Michael L. Perlin, Decoding Right to Refuse Treatment Law, 16 INT'L J.L. \& Psychiatry 151 (1993); Perlin et al., Therapeutic Jurisprudence, supra note 59, at 96103 (right to treatment). 


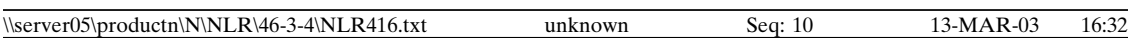

and conclude that TJ carries with it the potential to offer redemption for all mental disability law." 61 As I suggested, the use of therapeutic jurisprudence - to expose pretextuality and strip bare the law's sanist façade - will become a powerful tool that will serve as "a means of attacking and uprooting "the we/they distinction that has traditionally plagued and stigmatized the mentally disabled' - then that result will be therapeutic: for the legal system, for the development of mental disability law, and ultimately, for all of us:" 62

We cannot make any lasting progress in 'putting mental health into mental health law' until we confront the system's sanist biases and the ways that these sanist biases blunt our ability to intelligently weigh and assess social science data in the creation of a mental disability law jurisprudence.

I contend that therapeutic jurisprudence is our best strategy for confronting those biases. A practice based upon the tenets of therapeutic jurisprudence forces such lawyers to adopt a multi-disciplinary investigation and evaluation of the therapeutic effects of the lawyering process and a case's ultimate disposition. In therapeutic jurisprudence, the client's perspective should determine the therapeutic worth or impact of a particular course of events. As a scholarly matter, it is helpful to use therapeutic jurisprudence as a framework within which to investigate and reformulate areas of law reform aimed at resolving difficult societal dilemmas. As a practical legal tool, I believe that therapeutic jurisprudence has the farreaching potential to allow us to - finally - to come to grips with the pernicious power of sanism and pretextuality, and to offer us an opportunity to make coherent what has been incoherent - and to expose what has been hidden - for far too long. ${ }^{63}$

Why is this relevant? For this reason. A few years ago, TJ "broke out" of the mental disability law box, and began to look at many other aspects of the legal system: contracts law, tort law, gay rights law, medi-

61. Perlin, Hidden Prejudice, supra note 4, at 301.

62. Id.

63. Id. at 302-03. 
ation, preventive law, and so much more. ${ }^{64}$ Since TJ has done this, it has grown dramatically as a theoretical and jurisprudential force. ${ }^{65}$

This leads me to the current enterprise. Professor Pamela Champine has chosen to go where no law professor has ever gone. ${ }^{66}$ She is exploring, for the first time, the impact of sanism on trusts and estates law. By doing so, she inaugurates a new era in mental disability law scholarship. I hope that it will inspire others to consider this and other private areas of the law, and bring the concept of "sanism" to new and receptive audiences, including those that have never had prior reason to think much about mental disability law and its significance to their practice-based and scholarly interests.

One final comment. My title starts with a Bob Dylan quote. I initially thought of Things Have Changed ${ }^{67}$ simply because of the title: that things had changed. But the lyrics also added another level of connection. Listen to the chorus:

People are crazy and times are strange

I'm locked in tight,

I'm out of range,

I used to care, but things have changed. ${ }^{68}$

Dylan is a little more world-weary than I am, I guess. I still care, but he's right, of course, "things have changed." I believe that Professor Champine's new path will lead them to change even more.

64. See, e.g., KeY, supra note 59, at vii-x (listing articles).

65. As of March 4, 2002, the phrase "THERAPEUTIC JURISPRUDENCE" appears 514 times in the WESTLAW/JLR database.

66. Pamela Champine, A Sanist Will?, 46 N.Y.L Sch. L. Rev. 547 (2003).

67. Dylan, supra note 1.

68. Id. 
